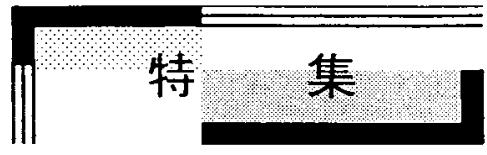

\title{
舶用ディーゼル機関のグリーン混相流技術*
}

\section{Green Multi-Phase Flow Technology for Marine Diesel Engine}

\author{
宋明 良** \\ SOU Akira
}

\begin{abstract}
Applications of multi-phase flow technologies to clean marine engineering are introduced. Large efforts have been made to reduce CO2, SOx, NOx and Particulate matter (PM) emissions from marine diesel engines. Urea Selective Catalytic Reduction (SCR) system is one of the most promising technology to largely reduce NOx emission. PM in exhaust gas may deposit on a honeycomb SCR catalyst, which increases pressure drop, blocks the flow area and decreases NOx reduction performance. Air blow (soot blow) can be effective for removing PM on a catalyst. An experimental investigation confirms that (1) large pore diameter of SCR catalyst and optimum exhaust gas velocity prevent PM accumulation, (2) PM accumulates mainly at the inlet and exit of the catalyst, and (3) high pressure soot blow removes PM.
\end{abstract}

Keywords: Marine engineering, Urea selective catalytic reduction, Particulate matter, Soot blow

\section{1. はじめに}

世界人口の爆発的増加と世界経済の発展を背 景に、世界の貿易量は年々増加し、今後も増加し 続けることが確実である。現在世界貿易で輸送さ れている貨物(燃料、食料、一般貨物を含む)のう ち重量ベースで 95\%以上が、安価で高効率な海上 輸送、即ち船舶による輸送に負っている。その結 果、世界の船舶から排出される二酸化炭素の量は ドイツ一国からの排出量に匹敵する。特に周囲を 海に囲まれエネルギー資源と食料に恵まれない 技術立国日本は、国際貨物の $99.6 \%$ 以上を海運に 依存しており、国内貨物輸送(トンキロ)の約 $40 \%$ を内航海運に頼っている[1,2]。

マリンエンジニア分野において混相流技術が 活用されている例として、空気潤滑法による船舶 抵抗低減[3]、マイクロバブルと衝撃波の相互作用 を利用したバラスト水(空荷になった船舶の安定 性を高めるために船内に取り込む海水)中の海洋 細菌や海洋微生物の殺滅処理[4]、ナホトカ号事故 やメキシコ湾事故などが記憶に新しい、流出油の
拡散防止と拡散過程数值予測[5]、同じく気象海象 数值予測を利用した高効率・低環境負荷・低リス クな航路決定[6]、キャビテーションを制御した高 効率スクリュープロペラ開発などがある。

\section{2. 舶用機関}

マリンエンジニアリングの核をなすのは舶用 機関である。歴史を振り返ると、遣隋使、遣唐使、 大航海時代をはじめ、船舶は人力や風力を主な推 進力としてきた。産業革命以降はレシプロ式蒸気 機関、その後熱効率が高く性能の優れた蒸気ター ビンが舶用機関として世界の主流となったが、デ イーゼル機関の出現と高性能化を受けて現在の 舶用機関のほとんどはディーゼル機関が採用さ れている。大型船舶で採用されている大型 2 ス卜 ローク低速ディーゼル機関は、高粘度で不純物や 硫黄分が多く含まれる安価な C 重油が燃料とさ れ、10〜14 気筒で総出力約 $80 \mathrm{MW}$ (10 万馬力) に達する。機関熱効率は、機関の大型化(シリン ダ直径 $1 \mathrm{~m}$ 弱) と長ストローク化( $3.5 \mathrm{~m}$ 以上)の恩恵

* 2013.2.11 受付

*** 神戸大学大学院海事科学研究科 $\bar{T} 658-0022$ 兵庫県神戸市深江南町 5-1-1

TEL: (078)431-6294 FAX: (078)431-6294 E-mail: sou@maritime.kobe-u.ac.jp 
を受けて 50\%超に達し、プロペラ推進効率を高め るため機関回転数は陸用機関に比べて非常に低 <60rpm 以下のものも多い。世界の多くの舶用機 関メーカーがライセンサ MAN Diesel 社などの技 術提携を受け、堅実な大型機関を大量に生産して いる[7]。また低燃費(低 $\mathrm{CO} 2$ ) のみならず、低 NOx、 低 SOx、低PMなどグリーン化が進められている。

ディーゼル機関の燃焼過程は複雑な化学混相 流乱流である。燃料インジェクタ内には Fig. 1 に 示すような非定常キャピテーションが生じて噴 射された液体燃料を劇的に分裂、霧状に微粒化さ せる[8]。噴霧は高温の燃焼室内で蒸発して周囲空 気と混合し、自着火して燃焼する。なお、高硫黄 燃料が利用される大型舶用機関の排ガス流は、粒 子状物質(PM)を多く含む固気二相流であり、PM は排ガス管内に装着された熱交換機や触媒の表 面に付着する[9]。

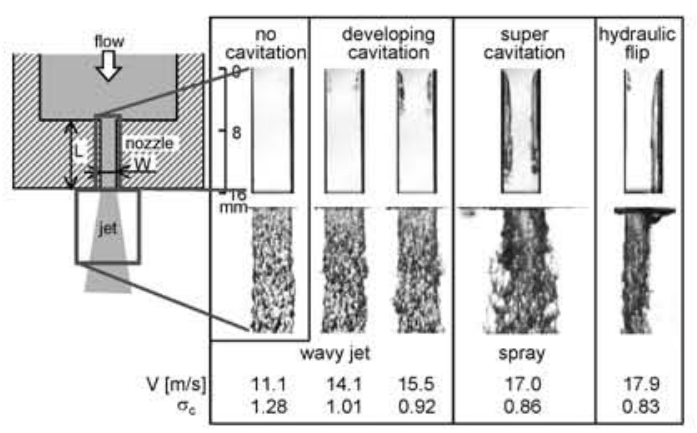

Fig. 1 Cavitation in an liquid injector [8].

SOx 低減には燃料の低硫黄化やスクラバー導 入、PM 低減には同じく低硫黄化燃料や燃料噴射 改善などが貢献する。スクラバーも燃料噴射技術 も混相流現象の制御が鍵となる。乙の他、舶用機 関の吸排気弁や燃料噴射系の電子制御化、バイオ 燃料、ガス燃料、燃料のダブルフューエル化、コ モンレール式燃料噴射、燃料電池、水素燃料、機 関ハイブリッド化など様々な新技術が検討され、 混相流計測制御技術が貢献している。

特にNOx については世界海事機関（IMO, International Maritime Organization)において Fig. 2 に示す 3 段階の規制が定められ、EGR (Exhaust Gas Recirculation、排ガス再循環)、弁開閉時期変 更によるミラーサイクル化、尿素 SCR（選択触媒 還元、Selective Catalytic Reduction）などの導入に
よって規定対策が実現しつつある。次章では特に NOx の 3 次規制対応に不可欠とされる尿素 SCR に関わる混相流現象を取り上げて概説する。

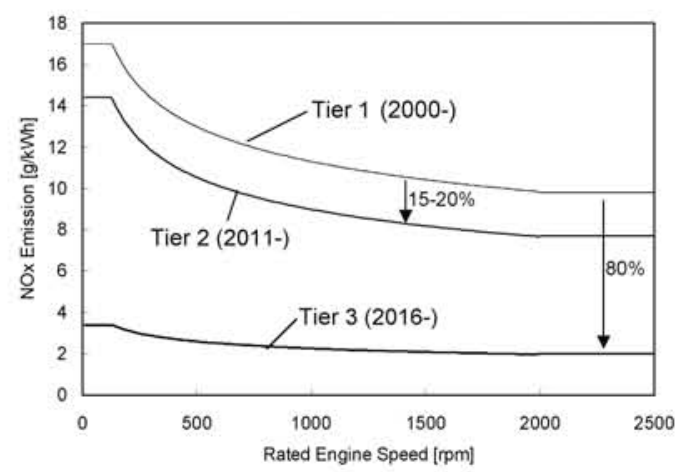

Fig. 2 IMO NOx regulations [10].

\section{3. 尿素 SCR における固気液混相流}

\section{1 尿素 SCR の概要}

尿素 SCR システムの主な構成模式図を Fig. 3 に示す。アンモニアより取り扱いの容易な尿素水 をディーゼル機関の排ガス管中に噴霧状に噴射 し、ミキサーなどで均一に混合させる。尿素水は 蒸発・加水分解してアンモニアとなり、Fig. 4 に 示すハニカム状の SCR 触媒において NOx 還元化 学反応を生じ、排ガス中の NOx を大幅に削減す る。NOx 排出量に対して過不足ないアンモニアの 供給、尿素水の均一混合、一定以上の排ガス温度、 一定以上の触媒滞留時間などの条件を満たせば、 $95 \%$ 以上の NOx 削減実績も多数報告されている。 一方で、尿素水の過剩噴射によるアンモニア排出、 尿素水の混合不良による NOx 鿇化率低下やアン モニア排出、PM 付着堆積による触媒の目詰り、 触媒容積の小型化など多くの課題が指摘されて いる[11-14]。

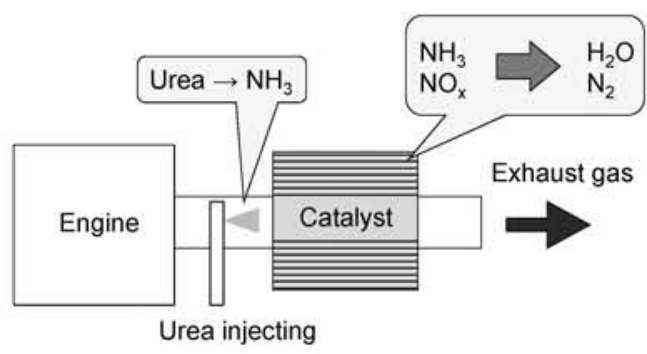

Fig. 3 Schematic of urea SCR system. 


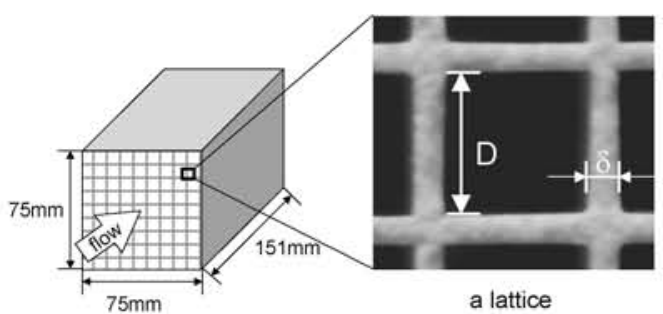

Fig. 4 Schematic of test SCR catalyst [9].

本報では、触媒容積小型化に不可欠なハニカム 状触媒の水力等価直径や排ガス線速度の影響調 查、触媒表面への PM 堆積状況把握、堆積した PM の除去方法の最適化、低圧損ミキサーによる 尿素水の均一混合などの著者らの研究結果[9]の 一部老概説する。

\section{2 実験装置と基礎実験結果}

Fig. 5 に実験装置の触媒部概念図を示寸[9]。PM を伴う高温排ガス管内の可視化は容易でないた め、触媒部圧損を計測した。また、触媒前面の一 部を覆い、排ガス線速度を変更した。様々な水力 直径の触媒を用いて実験し、それらの影響を調へ た。その結果、水力直径が過小だと短時間で PM が堆積して圧損が急増し、目詰まりを生じやすい こと、排ガス線速度が過大だとわずかな PM 堆積 で圧損が急増することなどを明らかにした。

Fig. 6 は長時間試験終了後の触媒上流側断面の 写真である。触媒の水力等価直径が小さい場合や 排ガス線速度が小さい条件などでは、このように PM が堆積する様子が観察された。なお、長時間 連続試験の途中で、燃料補給・潤滑油交換作業直 後の機関再起動時に、PM が除去され圧損が急减 する様子が見られた。これにより触媒に対する急 なガス供給 (スートブローと呼ばれる)によって、 堆積した PM を除去できる可能性が確認できた。

\section{3 スートブロー実験}

スートブローの構成の一案を Fig. 7 に示す。実 機では排気ダクト中に複数の触媒要素を多段構 成にして挿入する。圧縮空気のスートブローは各 触媒に対して上流側から極短時間直接噴射する。

長さ $150 \mathrm{~mm}$ および $304 \mathrm{~mm}$ の触媒に対して、0.8 $\mathrm{MPa}$ の空気圧で、 $230 \mathrm{~min}$ 周期で $0.5 \mathrm{~s}$ 間スートブ ローした際の圧損の計測結果を Fig. 8 に示す。矢 印で示したスートブローの瞬間に圧損が急減し ており、PMを一部除去できることを確認できた。

またスートブローを行わなかった場合、触媒長 さを長くしても、圧損の増加割合は同じであった
こと、実験後の触媒の画像、圧損計測結果と相関 式による圧損推算結果との比較から、PM はFig. 9 に模式的に示すように主に触媒入口部と出口部 に集中して堆積することを明らかにした[9]。

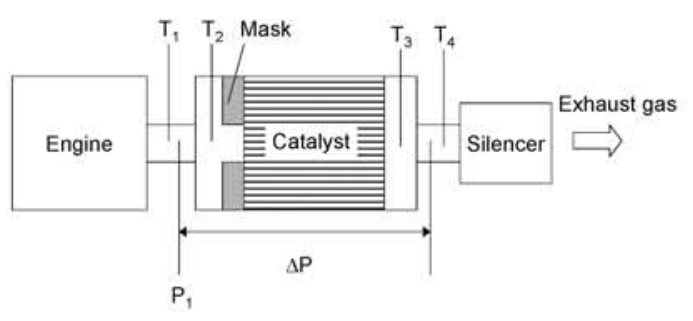

Fig. 5 Schematic of experimental setup.

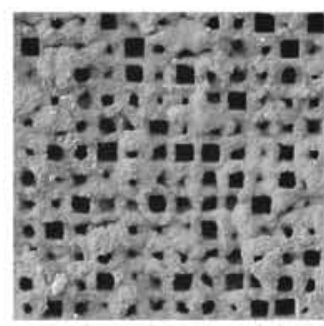

Fig.6 PM deposition on SCR catalyst.

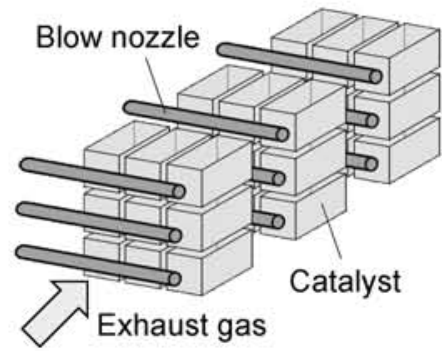

Fig. 7 Arrangement of catalysts with soot blow.

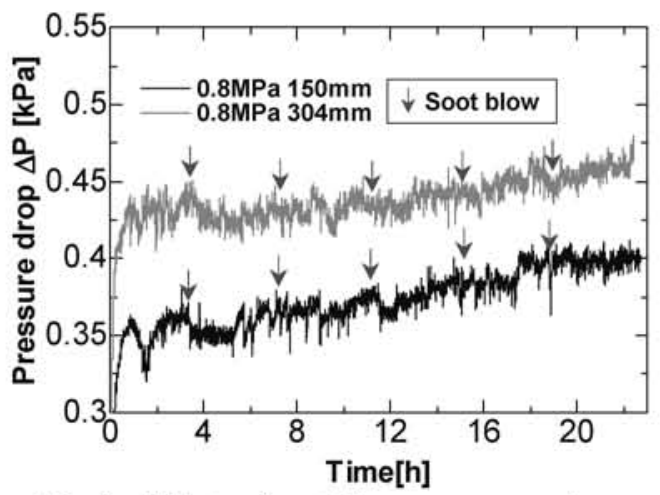

Fig. 8 Effects of soot blow on pressure drop. 


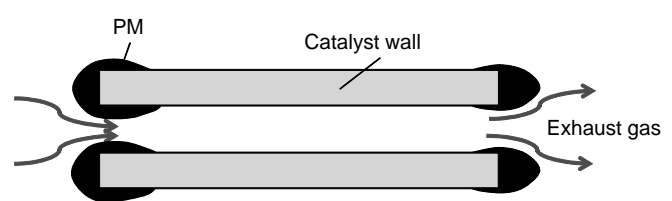

Fig. 9 PM accumulation profile.

\section{4. おわりに}

海上輸送に依存した世界的な貿易量の継続的 な増加をうけて、舶用機関からのCO2、NOx、SOx、 PM などの排出量や燃費を削減するために、様々 な混相流技術の導入が試みられている。本報では NOx 削減対策技術として現在最も期待されてい る尿素 SCR に関する混相流関連研究の一例を紹 介した。機関熱効率の数\%向上、プロペラ推進効 率の数\%向上、船体抵抗の数\%低減、太陽電池導 入による数\%総合熱効率向上、排熱利用による熱 効率の数\%向上、燃料改善、気象海象数值予報を 利用した航路最適化など、多面的な技術革新を積 み重ね、高効率でグリーンな海上輸送実現を目指 し、多くの研究開発が重ねられている。今後も多 くの混相流技術者・研究者がこれらに貢献される ことを期待する。

\section{謝 辞}

本研究の実施に当り神戸大学大学院海事科学 研究科学生とヤンマー株式会社のご協力を得た。 ここに謝辞を表します。

\section{参考文献}

[1] The Japanese Shipowners' A ssociation, http://www.jsanet.or.jp/ (in Japanese) (2013).

[2] M inistry of Land, Infrastructure, Transport and Tourism, http://www.mlit.go.jp/ (in Japanese) (2013).

[3] M urai, Y., Kumagai, I., Takasa, Y., Takeda, Y. and Takahashi, Y., Hydrofoil Type of Bubble Generator for Marine Drag Reduction, Transactions of the Japan Society of M echanical Engineers, Series B, Vol. 76 (763), 483-485 (2010).

[4] A be, A., Sou, A., Mimura, H. and Nishio, S.,
Application of Microbubbles and Shock Pressures to Ship's Ballast Water Treatment, Japanese J ournal of Multiphase Flow, Vol. 27 (1), in print (2013).

[5] Choi, Y., Takahashi, K., A be, A., Nishio, S. and Sou, A., Simulation of Deepwater Horizon Oil Spill Using Coupled A tmosphere-O cean M odel, Marine Engineering, Vol. 48 (1), 105-109 (2013).

[6] Shiotani, S., M imura, H. and A be, A ., Innovation of System for Reliability and Safety on Overseas Transportation, Japanese J ournal of Multiphase Flow, Vol. 23 (3), 305-314 (2009).

[7] MAN Diesel \& Turbo SE 2013, Products, http://www.mandieselturbo.com/ (2013).

[8] Sou, A., Hosokawa, S. and Tomiyama, A., Effects of Cavitation in a Nozzle on Liquid Jet A tomization, International J ournal of Heat and M ass Transfer, Vol. 50, Iss. 17-18, 3575-3582 (2007).

[9] Sou, A., Accumulation and Removal of Particulate $M$ atter on SCR Catalyst of $M$ arine Diesel Engine, Proc. Japan-U.S. Seminar on Two-Phase flow Dynamics 2012, No. T16 (2012).

[10] International Maritime Organization (IMO), http://www.imo.org/ (2013).

[11] Niki, Y., Hirata, K., Kishi, T., Ichikawa, Y. and Ohashi, S., Comparison of the NOx Reduction Performance of SCR Installed on Diesel Engine and the Estimated Performance from Catalyst Test Using Micro-R eactors, Proc. 9th Int. Symp. On M arine Engng. (ISME 2012), USB flash drive, C6-1 (2012).

[12] Christensen, H., Pedersen, M. F., Skjoldager, P. and Fam, M., Tier III SCR for Large 2-Stroke MAN B\&W Diesel Engines, Proc. 9th Int. Symp. On Marine Engng. (ISME 2012), USB flash drive, A 5-3 (2012).

[13] Imanaka, K., Yanagi, J., M iyanagi, A. and Watanabe, K., Exhaust Emission Control of $M$ itsubishi UE Diesel Engine, Proc. 9th Int. Symp. On Marine Engng. (ISME 2012), USB flash drive, C5-2 (2012).

[14] Wakatsuki, Y. and M isawa, K., NOx Reduction Performances of M arine SCR System, Proc. 9th Int. Symp. On Marine Engng. (ISME 2012), USB flash drive, C6-2 (2012). 